\title{
Experimental and Numerical Investigation of Self Compacting Reinforced Concrete Dapped End Beams Strengthened with CFRP Sheets
}

\author{
Qasim Mohammed Shakir \\ Baneen Basim Abd \\ Ali Talib Jasim \\ Department Building Materials, Engineering College, University of Kufa \\ qasimm.alabbasi@uokufa.edu.iq baneenbasim507@gmail.com alit.albozwaida@uokufa.edu.iq
}

\begin{abstract}
This study aims to investigate experimentally the behavior of self-compacting reinforced concrete dapped end beams strengthened with CFRP sheets and, then theoretically by ANSYS 15.0 software. The experimental program consists of testing 14-specimens each of dimensions $(200 \times 400 \times 1500 \mathrm{~mm})$ with two values of Shear span to depth effective (a/d), namely (1.5 and 1.0). Two of the beams are a control beams (with full reinforcement), and four beams with reduced reinforcement in hanger and nib regions. The other beams have been strengthened with several configurations by CFRP sheets for the same values of $(\mathrm{a} / \mathrm{d})$, the comparison between results included load-deflection curves and cracked specimens. It was found that the strut and tie model (STM) is very conservative somehow, reduction the nib reinforcements by about $(60 \%)$, in reduction in failure load by about (35\% and $15 \%)$ for the two values of $(\mathrm{a} / \mathrm{d})$. With respect to the strengthened specimens, it observed that the strengthening with inclined CFRP strips $\left(45^{\circ}\right)$ yielded better results in comparison with other configurations. The improvement in load capacity was about (23\%) for $(\mathrm{a} / \mathrm{d}=1.5$ and 1.0$)$. Also, it is found that the nonlinear model adopted in the present work compered the experimental tests yielded a good agreement with difference of about (12\%).
\end{abstract}

Keywords: - Dapped end beam, Shear span to depth effective (a/d), CFRP sheets, Self-compacting concrete.

\section{Introduction}

The connections are one of the most important elements that should be considered in design of precast concrete structures. The basic types of connections are using Corbel and beams with Dapped-end (DEB). The dapped-end beams are the precast members of concrete structures with reduced depth at end [1]. Many studied conducted on the behavior of DEB have been achieved Mattock and Chan, investigated the use of concepts design corbel on dapped ends some have been subjected to vertical load only, others subjected to a combination loads, they found that the reduction depth of dapped end may be designed as a corbel if it is taken the shear span (a) used in design equal to the distance from the center of action for vertical load to the center of gravity of the hanger reinforcement[2]. Wang et.al., tested 24 dapped end beams up to failure. The main variables studied were, the bent form of the longitudinal and the type and effective range (distance distribute of hanger stirrups) to provide the stirrups reinforcement, they observed that the inclined stirrups and longitudinal bent reinforcements were more effective on the shear capacity than the close and vertical stirrups [3]. Dhia S. and Khudair T., investigated experimentally and theoretically the behavior of pre-stress reinforced concrete dapped end beams, two strand profile were considered, namely (straight and draped) and compared 
failure load between experimental and numerical results by using ANSYS program, it was obtained that the finite element model behavior was stiffer than that of the tested specimen due to the effect of bond slip between the concrete and steel bars and the effect of micro cracks which were excluded in the finite element analysis, Also it is found that the pre-stress force was increased the ultimate loads capacity about (35\%) in case of straight strand and about (97\%) in case of draped strand, and there is a slight effect for both straight and draped strand profile on the response of flexural reinforcement up to crack which was varied in the range (5-12\%) for the deflection[4]. Amir W. et.al., tested full-scale single-tee pre-stress concrete beams with dapped ends with different reinforcement schemes: the vertical L, inclined L, vertical $\mathrm{Z}$, customs welded-wire reinforcements, vertical $\mathrm{C}$, and $\mathrm{CZ}$ schemes, the results showed the cracking at service load which can be reduced by extending the pre-stressing strand through the nib, using of the inclined $\mathrm{L}$ scheme, and use of a corner angle, also the inclined L scheme exhibited superior strength and serviceability compared with other schemes because the hanger reinforcement is nearly parallel to the diagonal tension field[5].

\section{Experimental Program}

\subsection{Materials}

\section{- Cement}

Ordinary Portland cement (Type I) that has been manufactured by (kar) company it is conformed to the Iraqi Specifications (IQ.S. 5/1984) [6].

\section{- Water}

Ordinary clean tap water was used for all proposes.

\section{- Fine Aggregate}

Normal sand with max size of $(10 \mathrm{~mm})$ that imparted from Al-Najaf zone in Iraq was used as fine aggregate. The fine aggregate grading and the sulfate content satisfied the Iraqi Specification requirements (IQ.S.45/1984) [7].

\section{- Coarse Aggregate}

The aggregate was crushed with maximum size of $(20 \mathrm{~mm})$ the absorption and specific gravity were $(0.75 \%)$ and (2.6) respectively the grading of gravel satisfied the requirements of the Iraqi specifications (IQ.S.45/1984) [8].

\section{- Limestone Powder}

Limestone powder was used as a filler to avoid excessive heat generation, enhance fluidity and cohesiveness, improve segregation resistance and increase the amount of fine powder in the mix (cement and filler). The particle size of the limestone powder met the requirements of EFNARC [8].

\section{- Super Plasticizer}

Super Plasticizer type GLENIUM®54 was used in this study [9].

\section{- Steel Reinforcing Bars}

Steel reinforcement consists of deformed bars with three sizes. Longitudinal reinforcement of $(16 \mathrm{~mm})$ diameter and $(\phi 10 \mathrm{~mm})$ used as stirrups, also, $(\phi 12 \mathrm{~mm})$ 
steel bars were used as a hanger reinforcement in hanger region. The properties materials for testing steel bars are listed in Table (1).

Table (1): Properties of Steel Bars

\begin{tabular}{|c|c|c|c|c|}
\hline $\begin{array}{c}\text { Nominal Bar } \\
\text { Diameter } \\
(\mathrm{mm})\end{array}$ & $\begin{array}{c}\text { Measured Bar } \\
\text { Diameter } \\
(\mathrm{mm})\end{array}$ & $\begin{array}{c}\text { Yield } \\
\text { Stress }^{*} \\
(\mathrm{MPa})\end{array}$ & $\begin{array}{c}\text { Ultimate } \\
\text { Stress } \\
(\mathrm{MPa})\end{array}$ & $\begin{array}{c}\text { Modulus of } \\
\text { Elasticity } \\
(\mathrm{MPa}) * *\end{array}$ \\
\hline 10 & 9.8 & 568 & 726 & 200000 \\
\hline 12 & 11.89 & 615 & 712 & 200000 \\
\hline 16 & 16.08 & 634 & 748 & 200000 \\
\hline
\end{tabular}

*Each value is an average of three specimens (each $50 \mathrm{~cm}$. length).

**Assumed value.

\section{- Carbon Fiber Reinforced polymer (CFRP) Sheets}

CFRP sheet strips type SikaWrap ${ }^{\circledR}-301 C$ [10] and Epoxy based impregnating resin of type Sikadur-330[11] have been used for strengthening of reinforced concrete dapped end beams. The properties CFRP sheets and Epoxy Resin are listed in Tables (2) and (3).

Table (2) Properties of Carbon Fiber Reinforced Polymer [10]

\begin{tabular}{|c|c|c|c|c|c|}
\hline Type & $\begin{array}{c}\text { Weight } \\
(\mathrm{g} / \mathrm{m} 2)\end{array}$ & $\begin{array}{c}\text { Thickness } \\
(\mathrm{mm})\end{array}$ & $\begin{array}{c}\text { Tensile } \\
\text { Strength } \\
(\mathrm{MPa})\end{array}$ & $\begin{array}{c}\text { Tensile } \\
\text { modulus } \\
(\mathrm{MPa})\end{array}$ & $\begin{array}{c}\text { Elongation } \\
\text { at break } \\
(\%)\end{array}$ \\
\hline $\begin{array}{c}\text { SikaWrap®- } \\
\text { 301 C }\end{array}$ & 304 & 0.167 & 4900 & 230000 & 1.7 \\
\hline
\end{tabular}

Table (3) Properties of Epoxy Resin (Sikadur-330) [11]

\begin{tabular}{|c|c|c|c|c|c|}
\hline Appearance & $\begin{array}{c}\text { Mixing ratio } \\
\text { (by weight) }\end{array}$ & $\begin{array}{c}\text { Tensile } \\
\text { strength } \\
(\mathrm{MPa})\end{array}$ & $\begin{array}{c}\text { Modulus of } \\
\text { elasticity } \\
(\mathrm{MPa})\end{array}$ & $\begin{array}{c}\text { Density } \\
(\mathrm{kg} / \mathrm{l}) \\
\text { mixed }\end{array}$ & $\begin{array}{c}\text { Elongation at } \\
\text { break \% }\end{array}$ \\
\hline $\begin{array}{c}\text { Com A: White } \\
\text { Com B: Gray }\end{array}$ & $\begin{array}{c}\mathrm{A}: \mathrm{B} \\
4: 1\end{array}$ & 30 & 4500 & 1.31 & 0.9 \\
\hline
\end{tabular}

\subsection{Concrete Mixture Design}

Self-compacting concrete with cylinder compressive and tensile strength $\left(\mathrm{fc}^{\prime}=45 \mathrm{MPa}\right)$ and $\left(\mathrm{f}_{\mathrm{t}}=4.2 \mathrm{MPa}\right)$ respectively was used. Mix design of $\mathrm{SCC}$ met the criteria on filling ability, flow ability, possibility and segregation resistance according to ACI Committee 237R-07[12].

\subsection{Description of Specimens}

Fourteen specimens have been tested, each of dimensions (200x400x1500 mm) with two values of $(\mathrm{a} / \mathrm{d})$ namely (1.5 and 1.0). Figure (1) shows the dimensions and steel reinforce for a typical beam. The specimens have been divided into two groups (A and B) in each group three specimens were tested as a control beams and other beams with CFRP sheets strengthening. two of the tested beams have been considerable as a control beams (with full reinforcement), and the other beams were reduced reinforcement in hanger and nib regions, the other beams have been strengthened with several configurations by CFRP sheets for the same values of $(a / d)$, 
to study the effects of these parameters on the performance of such elements beam. The control specimens were tested initially, the modes of failure are discussed and the propagation of the cracks was mentioned, studies the first type proposed of strengthening is installed, then observed the mode of failure, and reposes then suggested the second strengthening, as well for the second group.

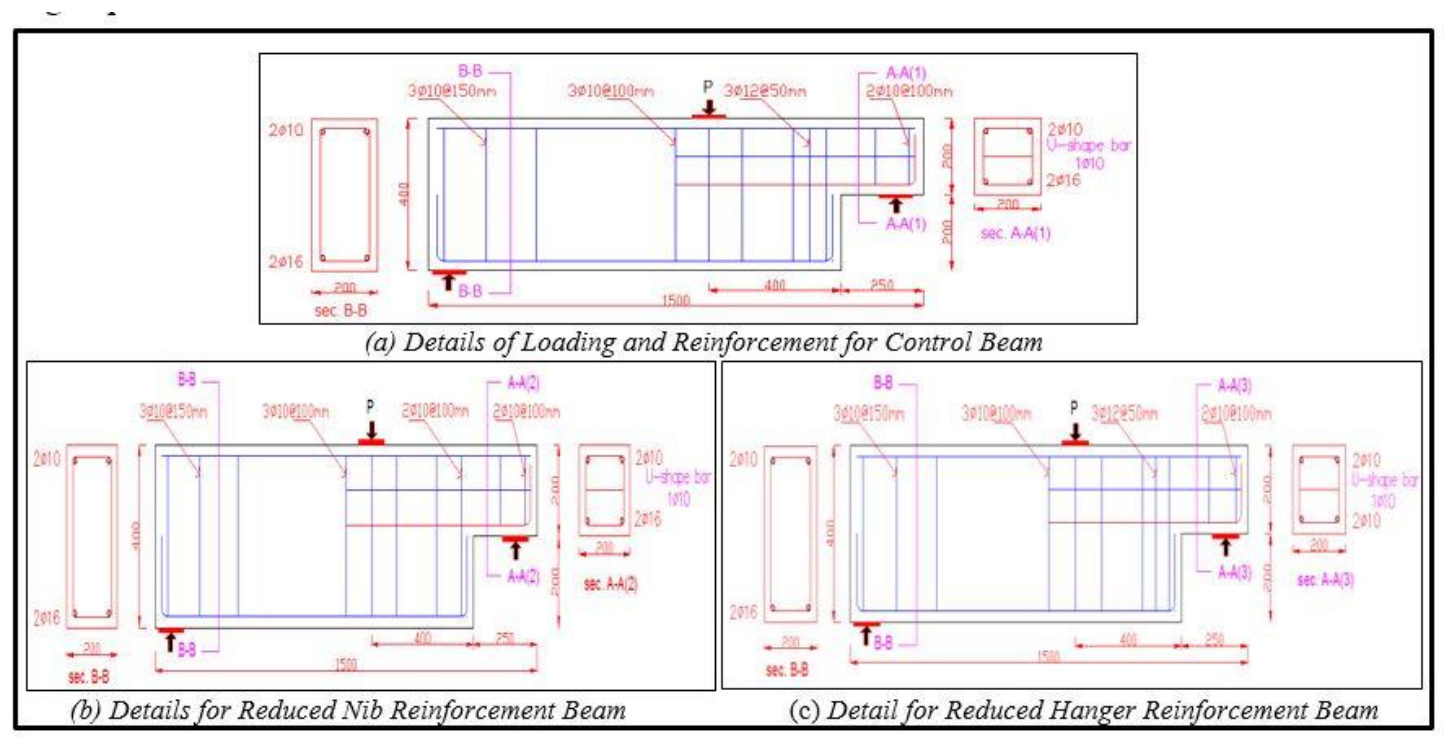

*All Dimensions in mm

Figure (1) Details of Reinforcement Beams

\subsection{CFRP Strengthening Systems}

The strengthening of specimens are selected carefully depended on the crack pattern of control beam, the field conditions and practical needs. In the program of research, eight dapped end beams were strengthened with externally bonded (CFRP) sheets as shown in Table (4), and the configurations of strengthening are shown in Figure (2).

Table (4) Characteristics of Tested Beams

\begin{tabular}{|c|c|c|}
\hline \multicolumn{2}{|c|}{ Symbol Beams } & CFRP Properties \\
\hline \multirow{7}{*}{$\frac{\sqrt{3}}{\frac{\pi}{2}}$} & CONT-A & None \\
\hline & HCONT-A & None \\
\hline & HSTR-1-A & 3-strips with angle $45^{\circ}$ \\
\hline & HSTR-2-A & $\begin{array}{c}\text { 2-vertical strips U-shape in hanger and nib+ 2-horozotal strips in nib } \\
\text { face }\end{array}$ \\
\hline & NCONT-A & None \\
\hline & NSTR-1-A & L-shaped sheet 1-layer \\
\hline & NSTR-2-A & L-shaped sheet 1-layer + 2-horozotal sheet in each face \\
\hline \multirow{7}{*}{ 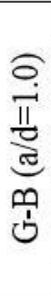 } & CONT-B & None \\
\hline & HCONT-B & None \\
\hline & HSTR-1-B & 3-strips with angle $45^{0}$ \\
\hline & HSTR-2-B & 2-vertical -U-shape in hanger and nib +2 -horozotal strips in nib face \\
\hline & NCONT-B & None \\
\hline & NSTR-1-B & 3-horizontal strips in nib face +2 -vertical U-shape in hanger \\
\hline & NSTR-2-B & 3-horizontal strips in nib face +3 -strips with angle $45^{\circ}$ \\
\hline
\end{tabular}

H: reduced hanger reinforcement by $60 \%$

$\mathrm{N}$ : reduced Nib reinforcement by $60 \%$

All strips with width $50 \mathrm{~mm}$ 


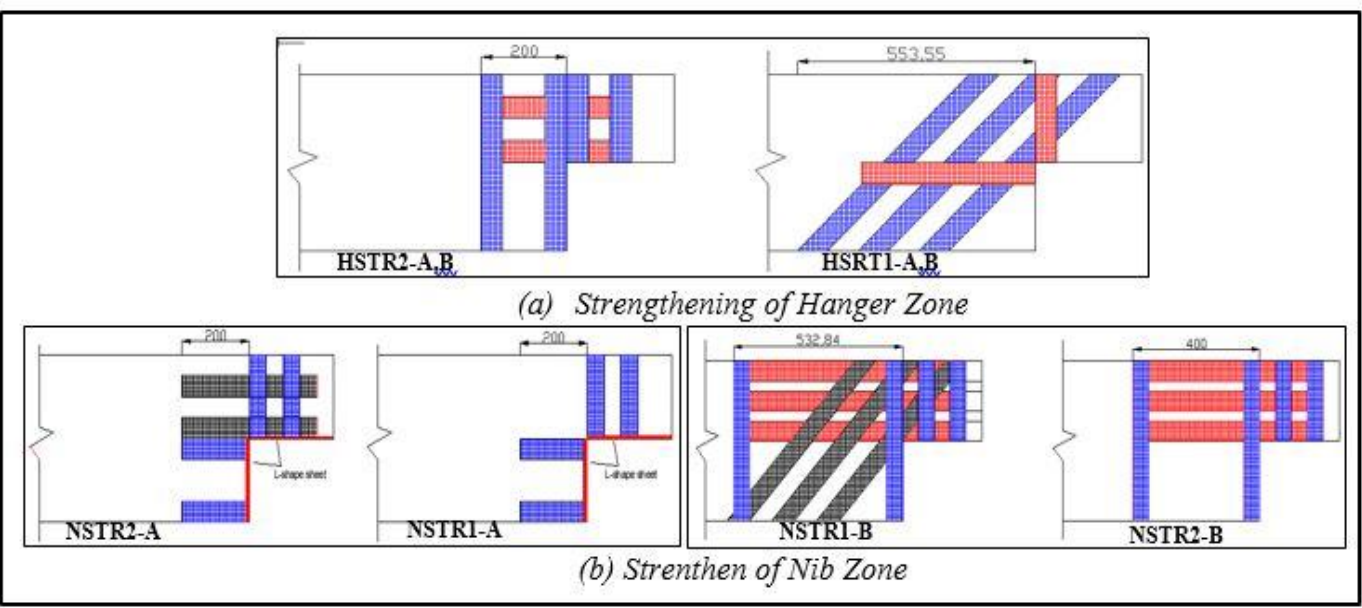

Figure (2) Strengthening Configurations of Dapped end Beams

\subsection{Test Setup and Instrumentation}

\subsubsection{Supporting and Loading Condition}

All beam specimens are tested in a universal testing machine at University of Kufa, with maximum capacity of $1000 \mathrm{KN}$. The test specimens are simply supported over a span of $1260 \mathrm{~mm}$ and 1340 for shear span to depth ratio (1 and 1.5) receptively, steel bearing plate of $(100 \times 200 \times 10 \mathrm{~mm})$ inserted between the concrete and steel roller to prevent local failure at the supporting and loading points, and loaded with one-point load apply and distribute the load through roller support across the entire width of the beams, as shown in Figure (3).
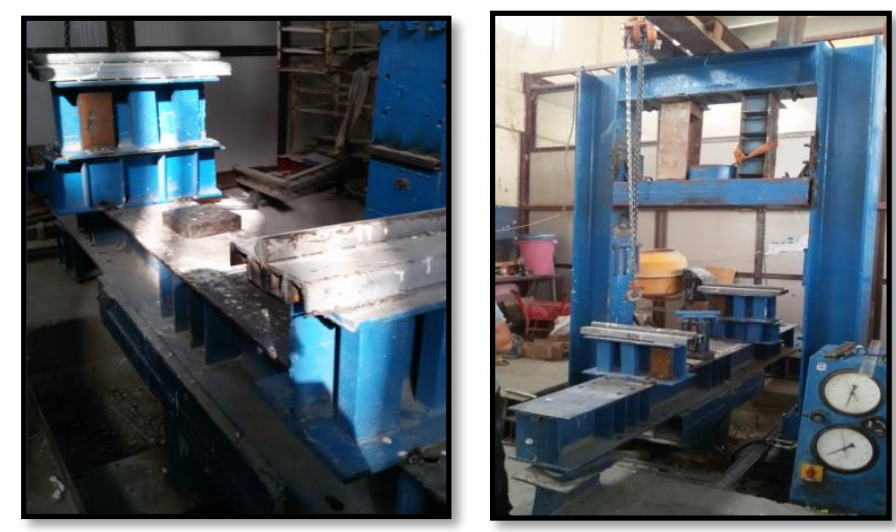

Figure (3): Supports and loads condition

\subsubsection{Instrumentation Tools}

At each test, deflection, width of cracks, concrete strain, crack load and ultimate load were recorded :

The tools, which are used during the test, are as follows blew:

1- Dial gauge (reading accuracy of $0.01 \mathrm{~mm}$ ) to calculate deflection .

2- Mechanical extensometer to calculate strain in concrete.

3- Zooming in tool to measure crack width . 
Figure (4) shows the tools that were used during testing the beams.

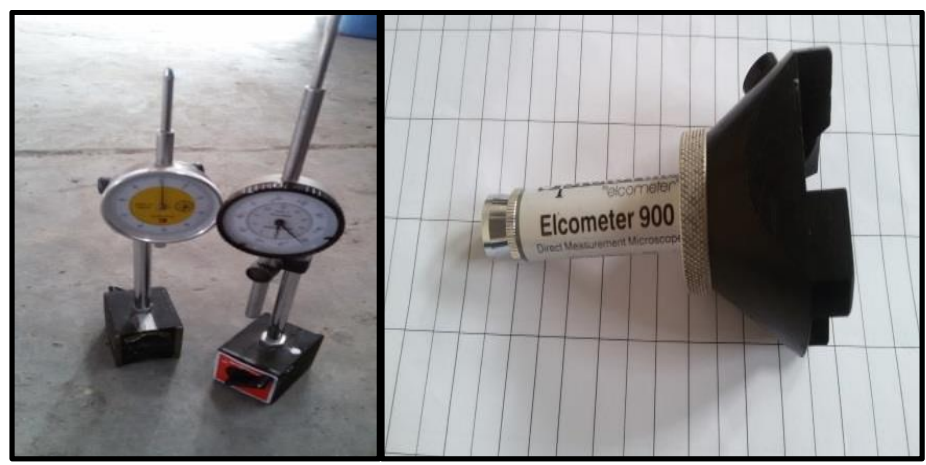

(b)Mechanical Extensomete $\quad$ (c) Micro Cracks Reader

Figure (4) Tools Used for the Tested Beams

\subsubsection{Testing Procedure}

All the specimens were dyed with white color to see the development of cracks. Initially, the beams were loaded by $(5 \mathrm{KN})$ to stabilize the supports and the loading system, then, unloading to zero. A convenient test frame was available at the Structure Laboratory of the College of Engineering at University of Kufa. All the beams were tested under monotonically increasing load up to failure. After failure, the cracks were marked with a heavy felt pen and the beam was photographed. Figure (5) explains the steps of testing procedure.

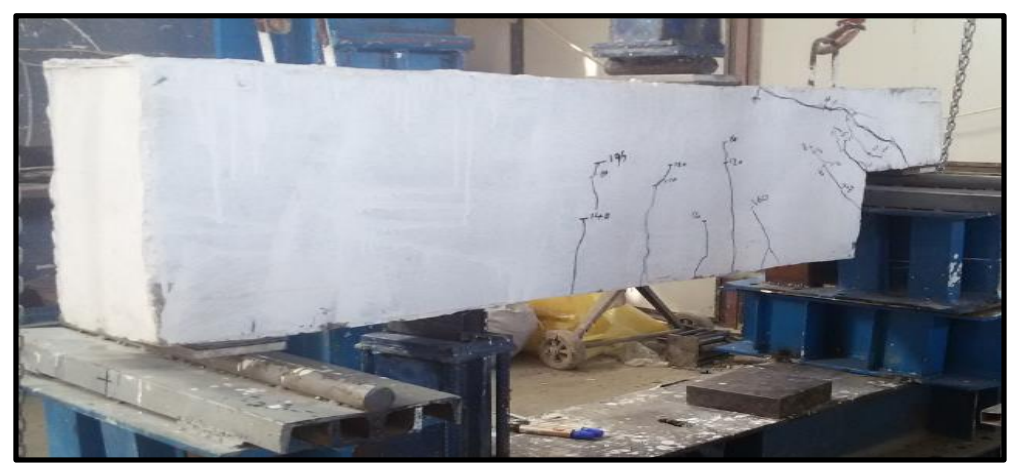

Figure (5) Test of Specimens

\section{Finite Elements Analysis}

\subsection{Modeling of the Structure}

By taking advantage of symmetry in Z-direction, only a half of the specimen was considered in the simulation. This results in an important reduction in the required computer disk space and the time to a chive analysis. Figure (6) shows a typical meshing discretization for a typical dapped end beam.

Link 180 was used to represent the steel reinforcement, whereas Solid 65 and Shell 41 to represent concrete element and CFRP sheets used for strengthening respectively. A steel plate of $(100 \times 100 \times 10 \mathrm{~mm})$ are used at supports and loading point to prevent the stress concentrations, and molded by using Solid 45 elements. Each inter nodes resist twice the external nodes. Figure (7) shows the simulation of the steel reinforcement. 
Journal of University of Babylon for Engineering Sciences, Vol. (26), No. (7): 2018.

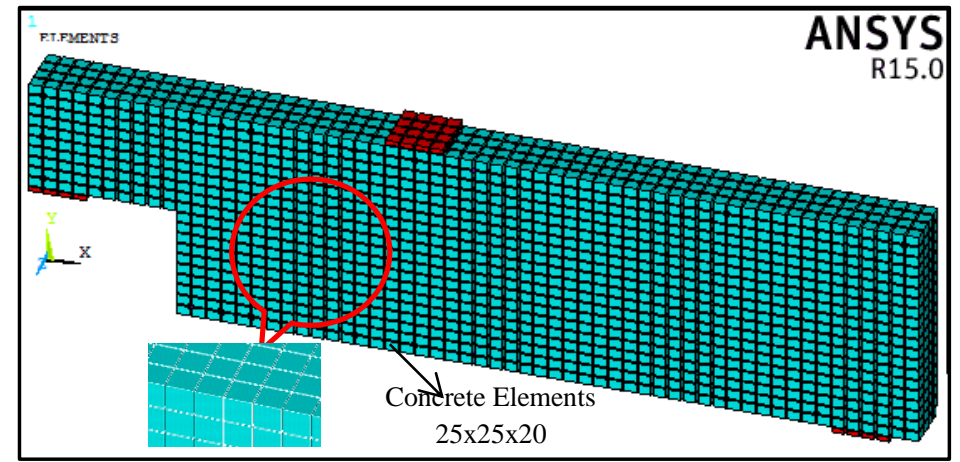

Figure (6) Discretization of meshing for Dapped end Beam

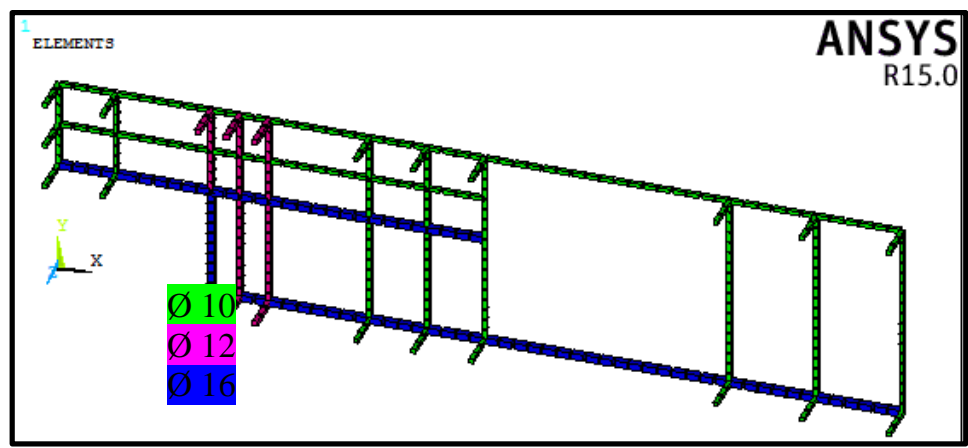

Figure (7) Typical of Steel Reinforcement Simulation

\subsection{Materials Modelling}

Figure (8) and (9) shows the compressive and tension model respactively that was adopted in this study and steel reinforcement it is assumed to be bilinear isotropic as shown in Figure (10). The CFRP sheets is assumed to be orthotropic material, where the properties of the FRP composites are the same in any direction perpendicular to the fibres. The modulus of elasticity was taken to be (230GPa) and the Poisson's ratio was assumed to be equal to zero.

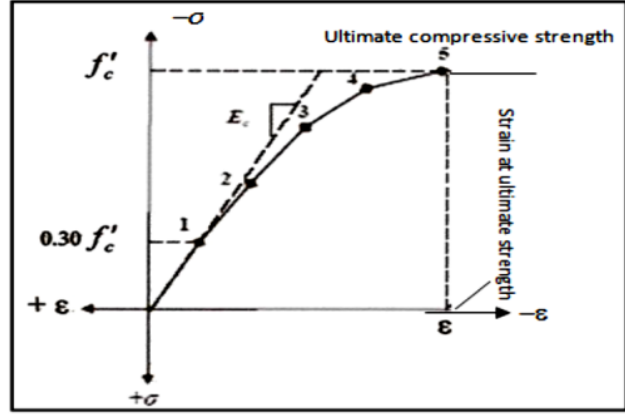

Figure (8) Stress-Strain Curve for Concrete in Compression

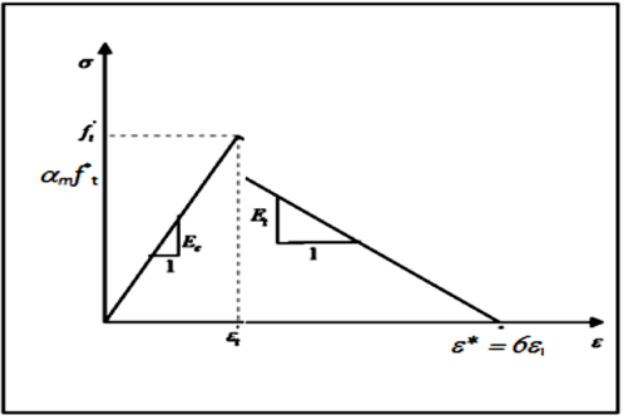

Figure (9) Tension Stiffening Model for Concrete 


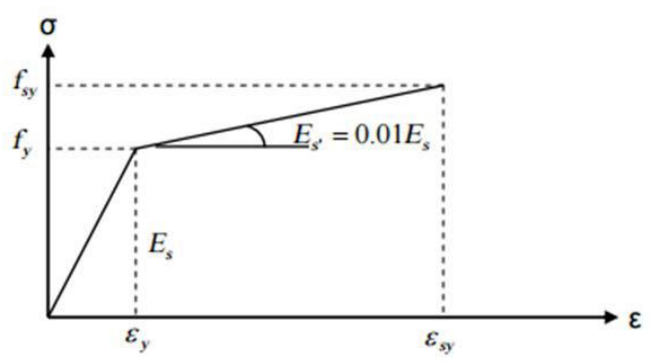

Figure (10) Stress-Strain Curve for Steel

\subsection{Loading and Boundary Condition}

Boundary conditions need to apply at points of symmetry and the supports, the nodes on the plane of symmtrey are restricted in the perpendicular direction. Figure (11) illustrates the steel load plate and the applied load.

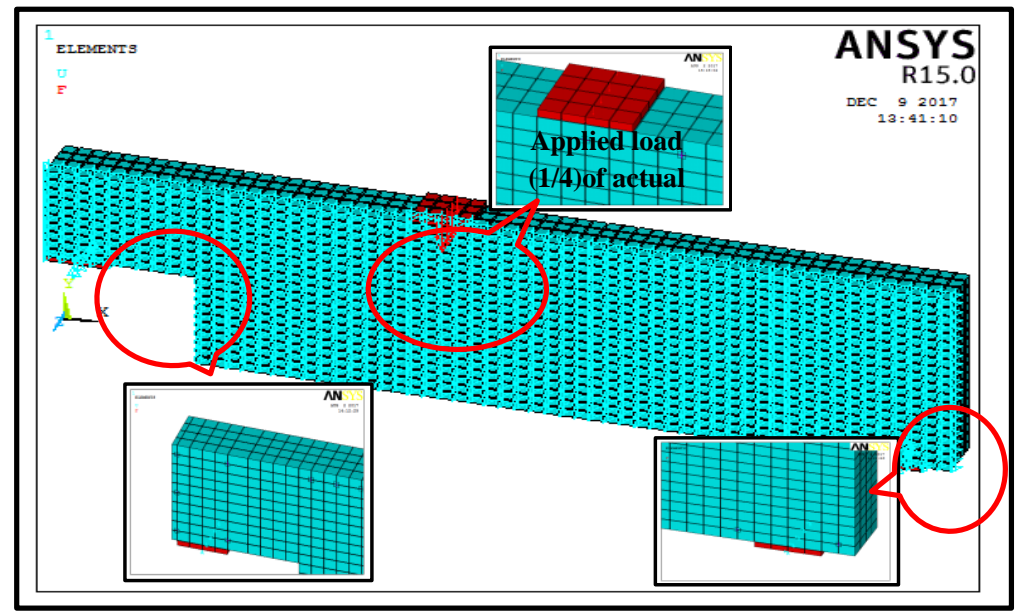

Figure (11) Boundary Conditions for Plane of Symmetry and load Supports

\section{Test Results}

The comparison in results includes: First cracking loads, load-deflections curves, ultimate loads, and cracking pattern.

\subsection{First Cracking Loads}

The comparison results of the first cracks load between experimental and numerical showed that the values obtained theoretically for all tested beams was higher than the experimental results with an average variance about (17\%) due to neglecting the effect of bond slip between the concrete and steel bars, as shown in Table (5). 
Journal of University of Babylon for Engineering Sciences, Vol. (26), No. (7): 2018.

Table (5) Experimental and Numerical Results of the First Cracking Loads

\begin{tabular}{|c|c|c|c|c|}
\hline \multirow{2}{*}{$(\mathrm{a} / \mathrm{d})$ ratio } & \multirow{2}{*}{$\begin{array}{c}\text { Specimens } \\
\text { Symbol }\end{array}$} & \multicolumn{2}{|c|}{ Cracking Load Pcr $(\mathrm{kN})$} & \multirow{2}{*}{ (FEM/Exp.) Ratic } \\
\hline & & Experimental & FEM & \\
\hline \multirow{7}{*}{ 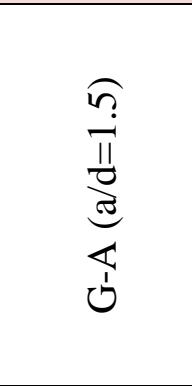 } & CONT-A & 40 & 35.5 & 0.88 \\
\hline & HCONT-A & 35 & 37.2 & 1.06 \\
\hline & HSTR1-A & 75 & 65 & 0.86 \\
\hline & HSTR2-A & 50 & 50 & 1.0 \\
\hline & NCONT-A & 25 & 35 & 1.19 \\
\hline & NSTR1-A & 35 & 40 & 1.14 \\
\hline & NSTR2-A & 50 & 50 & 1.0 \\
\hline \multirow{7}{*}{ 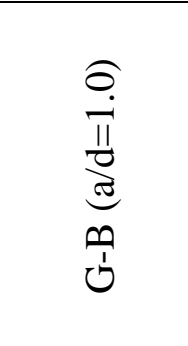 } & CONT-B & 50 & 55.5 & 1.15 \\
\hline & HCONT-B & 25 & 29.4 & 1.17 \\
\hline & HSTR1-B & 75 & 77.5 & 1.03 \\
\hline & HSTR2-B & 100 & 100 & 1.0 \\
\hline & NCONT-B & 20 & 22.4 & 1.12 \\
\hline & NSTR1-B & 70 & 80 & 1.14 \\
\hline & NSTR2-B & 75 & 82 & 1.09 \\
\hline
\end{tabular}

\subsection{Load - Deflection Curves}

The results obtained from the FE analysis for the load-deflection curves are plotted against that experimentally obtained and shown in figures (12) to (25). The presentation also includes a comparison between the experimental and numerical results as shown in Table (6). It can be seen that there is a good agree between theoretical and experimental results with a max different of (12\%).

Table (6) Experimental and Numerical Results for Ultimate Loads

\begin{tabular}{|c|c|c|c|c|}
\hline \multirow{2}{*}{$(\mathrm{a} / \mathrm{d})$ ratio } & \multirow{2}{*}{$\begin{array}{c}\text { Specimens } \\
\text { Symbol }\end{array}$} & \multicolumn{2}{|c|}{ Ultimate Load $\mathrm{Pu}(\mathrm{kN})$} & \multirow{2}{*}{$\begin{array}{c}\text { (FEM/Exp.) } \\
\text { Ratio }\end{array}$} \\
\hline & & Experimental & FEM & \\
\hline \multirow{7}{*}{ 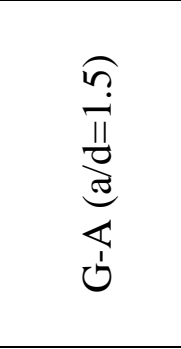 } & CONT-A & 285 & 279.09 & 0.98 \\
\hline & HCONT-A & 248 & 236.32 & 0.95 \\
\hline & HSTR1-A & 300 & 303.47 & 1.01 \\
\hline & HSTR2-A & 280 & 275.52 & 0.98 \\
\hline & NCONT-A & 180 & 172.4 & 0.96 \\
\hline & NSTR1-A & 185 & 185 & 1.0 \\
\hline & NSTR2-A & 200 & 201.5 & 1.01 \\
\hline \multirow{7}{*}{ 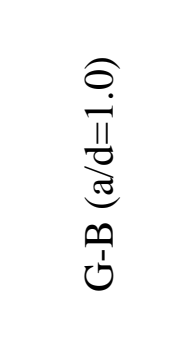 } & CONT-B & 300 & 305.24 & 1.02 \\
\hline & HCONT-B & 261 & 264.2 & 1.01 \\
\hline & HSTR1-B & 340 & 328.72 & 0.967 \\
\hline & HSTR2-B & 320 & 304.22 & 0.95 \\
\hline & NCONT-B & 255 & 245.36 & 0.96 \\
\hline & NSTR1-B & 290 & 291.91 & 1.00 \\
\hline & NSTR2-B & 300 & 310.2 & 1.034 \\
\hline
\end{tabular}


Journal of University of Babylon for Engineering Sciences, Vol. (26), No. (7): 2018.

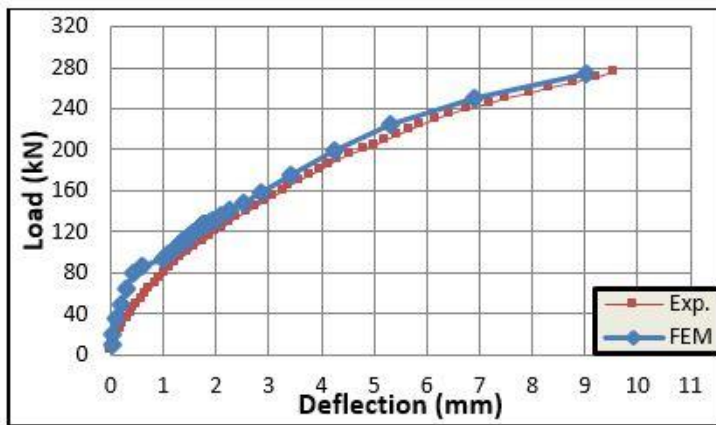

Figure (12) Load-deflection Curves of Specimen CONT-A

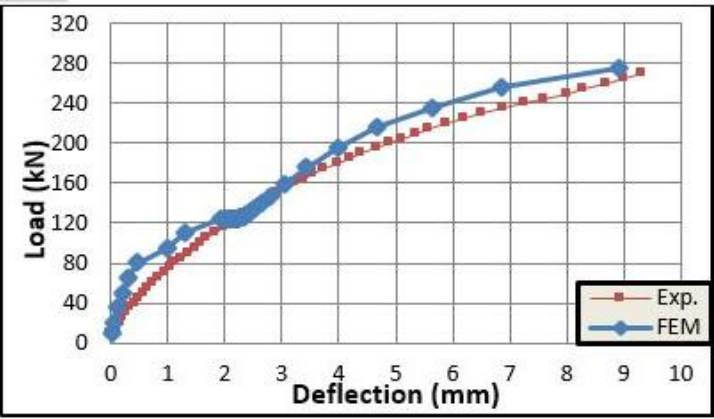

Figure (14) Load-deflection Curves of Specimen HSTR1-A

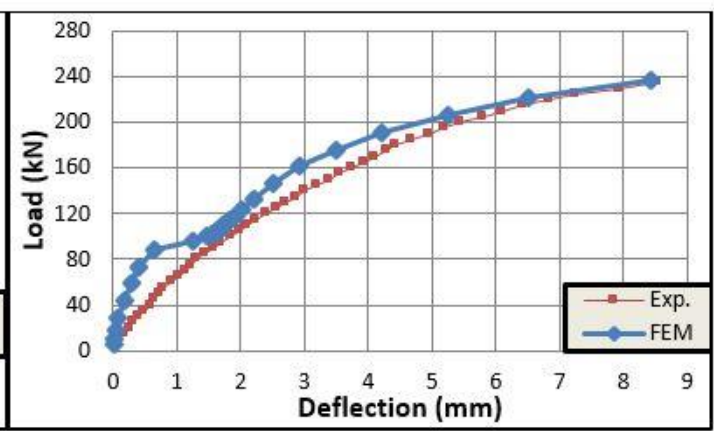

Figure (13) Load-deflection Curves of Specimen HCONT-A

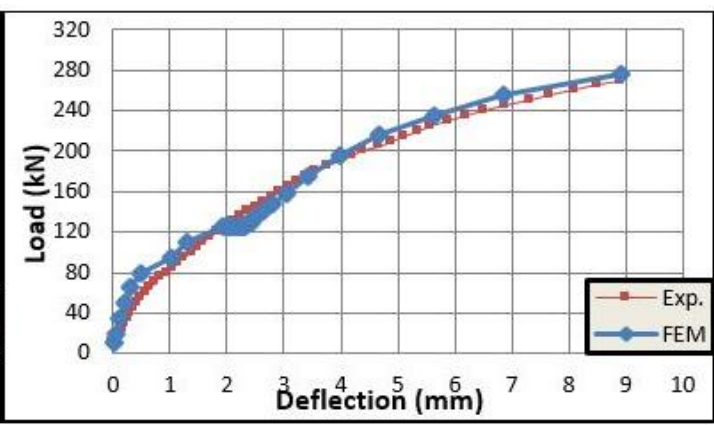

Figure (15) Load-deflection Curves of Specimen HSTR2-A

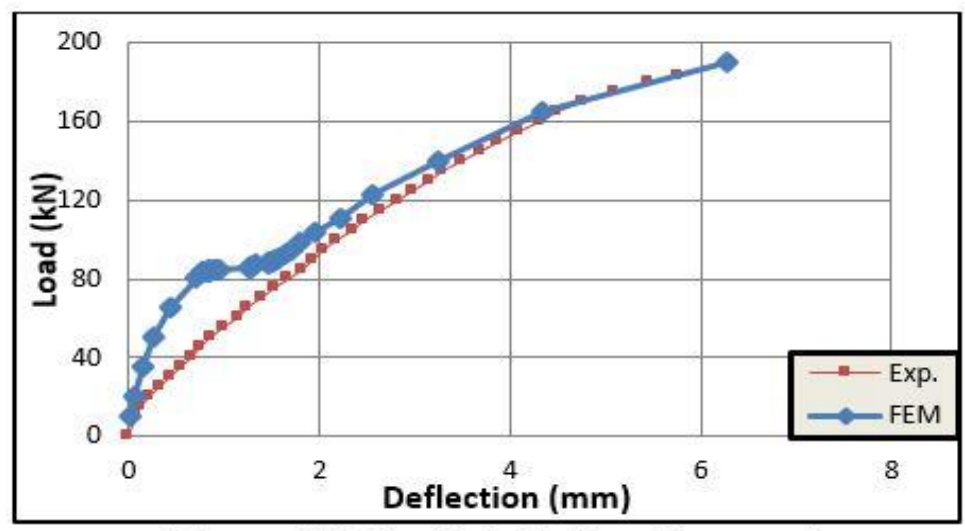

Figure (16) Load-deflection Curves of Specimen NCONT-A

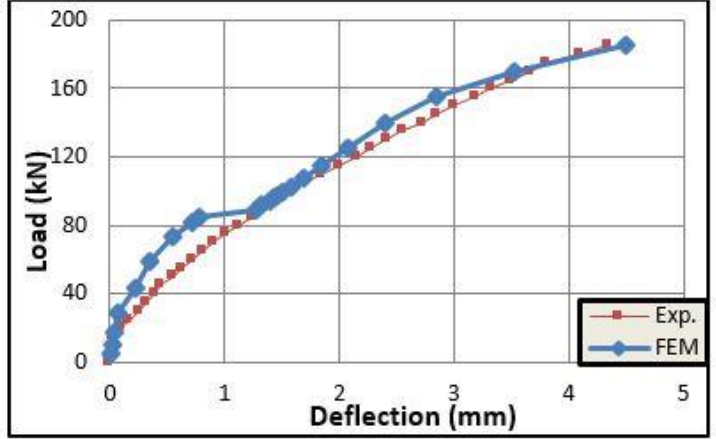

Figure (17) Load-deflection Curves of Specimen NSTR1-A

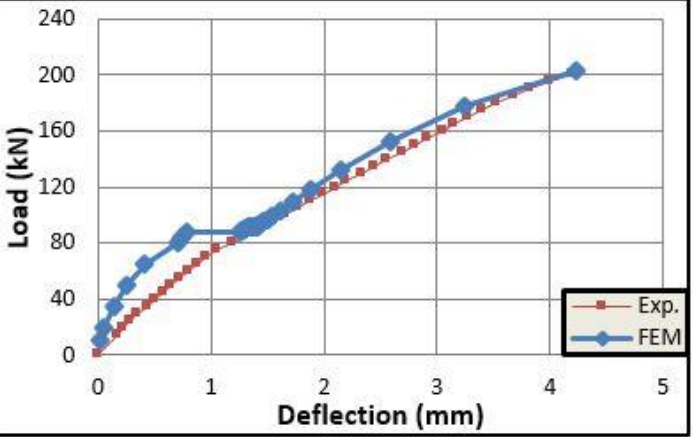

Figure (18) Load-deflection Curves of Specimen NSTR2-A 
Journal of University of Babylon for Engineering Sciences, Vol. (26), No. (7): 2018.

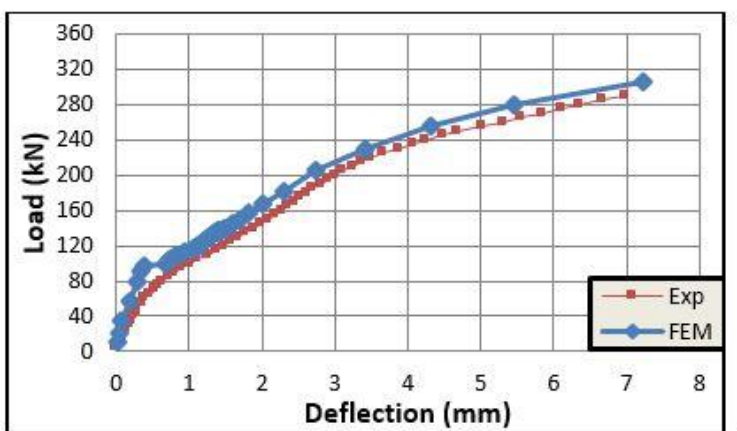

Figure (19) Load-deflection Curves of Specimen CONT-B

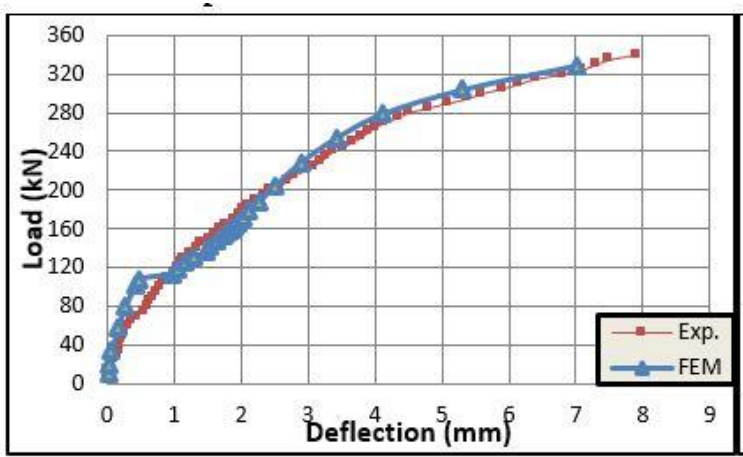

Figure (21) Load-deflection Curves of Specimen HSTR1-B

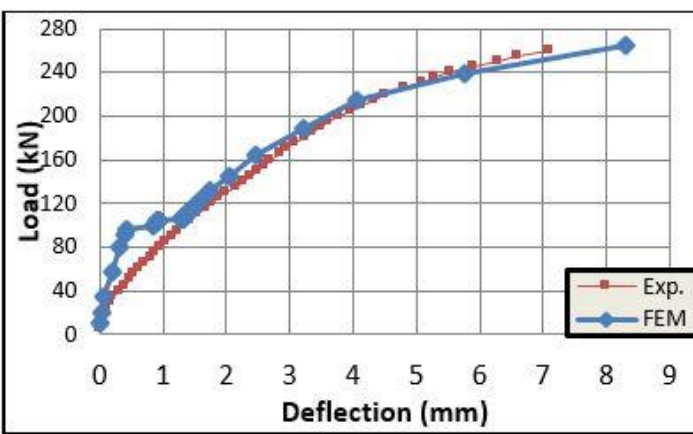

Figure (20) Load-deflection Curves of Specimen HCONT-B

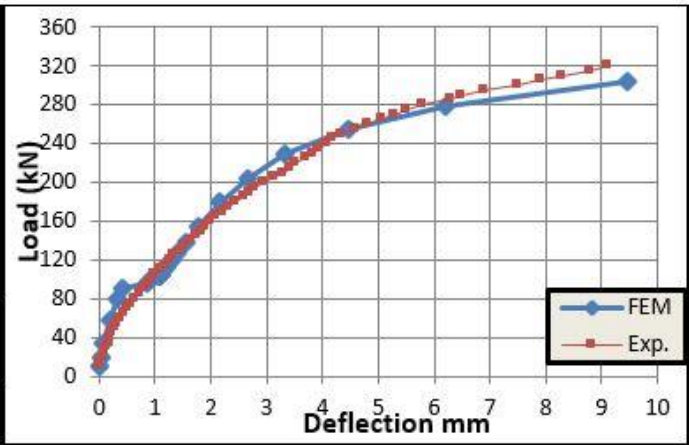

Figure (22) Load-deflection Curves of Specimen HSTR2-B

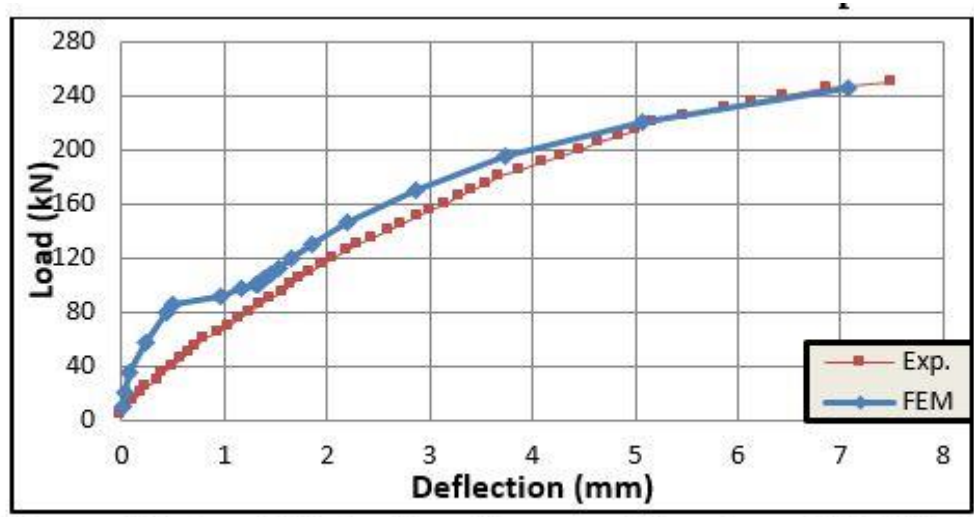

Figure (23) Load-deflection Curves of Specimen NCONT-B

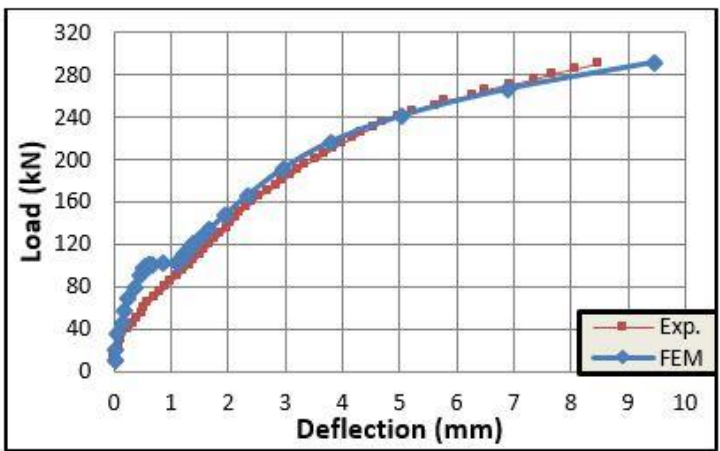

Figure (24) Load-deflection Curves of Specimen NSTR1-B

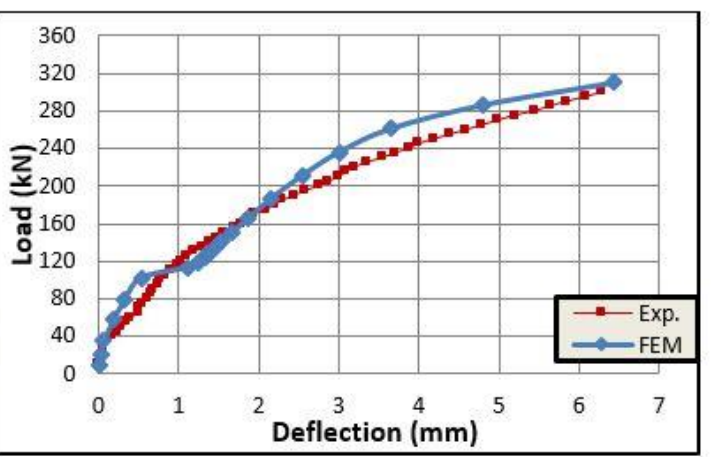

Figure (25) Load-deflection Curves of Specimen NSTR2-B 
Journal of University of Babylon for Engineering Sciences, Vol. (26), No. (7): 2018.

\subsection{Effect of Shear Span to Effective Depth Ratio (a/d)}

The effect of shear span to depth ratio $(\mathrm{a} / \mathrm{d})$ on behavior was investigated in this research work with two values (a/d) ratios (1.5) and (1.0). Table (6) shows the predicted ultimate shear strength obtained using these ratios.

In strengthened dapped ends for group A with $(\mathrm{a} / \mathrm{d}=1.5)$ for specimens (HSTR1A, HSTR2-A, NSTR1-A, and NSTR2-A), the increased load capacity approximately $(17.33 \%, 11.43 \%, 2.7 \%$, and $10 \%)$ with respect to the specimens (HCONT-A) and (NCONT-A), respectively. Failure mode was characterized by shear-flexural failure for HSTR-A and diagonal shear failure for (NSTR-A).

On the other hand, the load capacity for group B with $(\mathrm{a} / \mathrm{d}=1.0)$ the strengthened specimens (HSTR1-B, HSTR2-B, NSTR1-B, and NSTR2-B) increased approximately $(23.24 \%, 18.44 \%, 13.56 \%$, and $15 \%)$ with respect to control specimen (HCONT-B) and (NCONT-B), respectively. Failure mode can be classified as flexural shear failure.

It can be noted that strengthening technique with CFRP sheets for specimens with smaller $(\mathrm{a} / \mathrm{d})$ ratio had more effect on ultimate load from those of specimens with larger $(\mathrm{a} / \mathrm{d})$ ratio and changed mode of failure due to flexural behavior. This is evident in that the effect of CFRP sheets is more in the case of the smaller $(\mathrm{a} / \mathrm{d})$ ratio in a direction of flexural failure and the reason back to important feature for CFRP sheets is high tensile stress rather than dowel or transverse shear action.

\subsection{Effect of Configuration of CFRP Sheets}

The configuration of CFRP sheets was proved to be an active parameter of strengthening dapped ends. The test results showed a high effect of CFRP sheets orientation on cracking pattern and ultimate load capacity.

In strengthened specimen with sheet CFRP along the bottom face of dapped end (NSTR1-A) and (NSTR2-A), the decreased in the diagonal shear cracks, flexural shear cracks and increased ultimate loads of about $(46.43 \%, 60.7 \%),(41 \%, 56.8 \%)$ and $(2.7 \%, 10 \%)$, respectively.

The change in the configuration of strengthen for three strips in the horizontal direction at each face for (NSTR1-B), and three strips with angle $\left(45^{\circ}\right)$ at each face for (NSTR2-B), this is because it is vertical and inhibit the diagonal shear crack. Both specimens failed in shear flexure in the full depth portion of the member before failure of the dapped end, causes an decrease in the diagonal shear cracks, flexural shear cracks and increase ultimate loads of about $(85.6 \%, 92 \%),(40.5 \%, 64.3 \%)$ and $(13.56 \%, 15 \%)$, respectively.

The strengthening of specimens (HSTR1-A) and (HSTR1-B) were with three strips with angle $\left(45^{0}\right)$ at each face, both specimens failed in shear flexure in the full depth portion of the member before the failure of the dapped end, causing an decrease in the diagonal shear cracks, flexural shear cracks and increasing ultimate loads of about $(86.32 \%, 47.5 \%),(77.78 \%, 57.14 \%)$ and $(17.33 \%, 23.23 \%)$, respectively.

Also the strengthening of specimens (HSTR2-A) and (HSTR2-B) were with four strips in the vertical direction, two in the dapped and other in the hanger region at each face. Both specimens failed in shear flexure in the full depth portion of the member before failure of the dapped end. These strengthening influences the decrease 
in the diagonal shear cracks, flexural shear cracks and increases ultimate loads of about $(77.89 \%, 32.5 \%),(66.67 \%, 42.85 \%)$ and $(15.93 \%, 18.43 \%)$, respectively.

\subsection{Cracking Load and Crack Patterns}

In all control specimen dapped ends, the first crack was diagonal reentrant corner starting in the corner of the dapped end. The other cracks were diagonal tension crack in the extended end formed at or near support of dapped end.

Compared between two ratio of a/d, it was found that the cracks in small $(\mathrm{a} / \mathrm{d}=1.0)$ were lesser than cracks in large ratio. The diagonal shear cracks in all control beams were higher than the flexural shear cracks, but when strengthened dapped ends specimens (HSTR1-A, HSTR2-A, HSTR1-B, HSTR2-B, NSTR1-B, and NSTR2-B), the flexural cracks became higher than the diagonal shear crack.

The crack patterns for the tested specimen as obtained experimentally and from ANSYS software are shown in figure (25) to figure (38). These cracks were selected at the failure point. It is clear that the initial crack generated at the re-entrant corner of the dapped-ends and extends then after toward the applied load this is convenient with the experimental test.

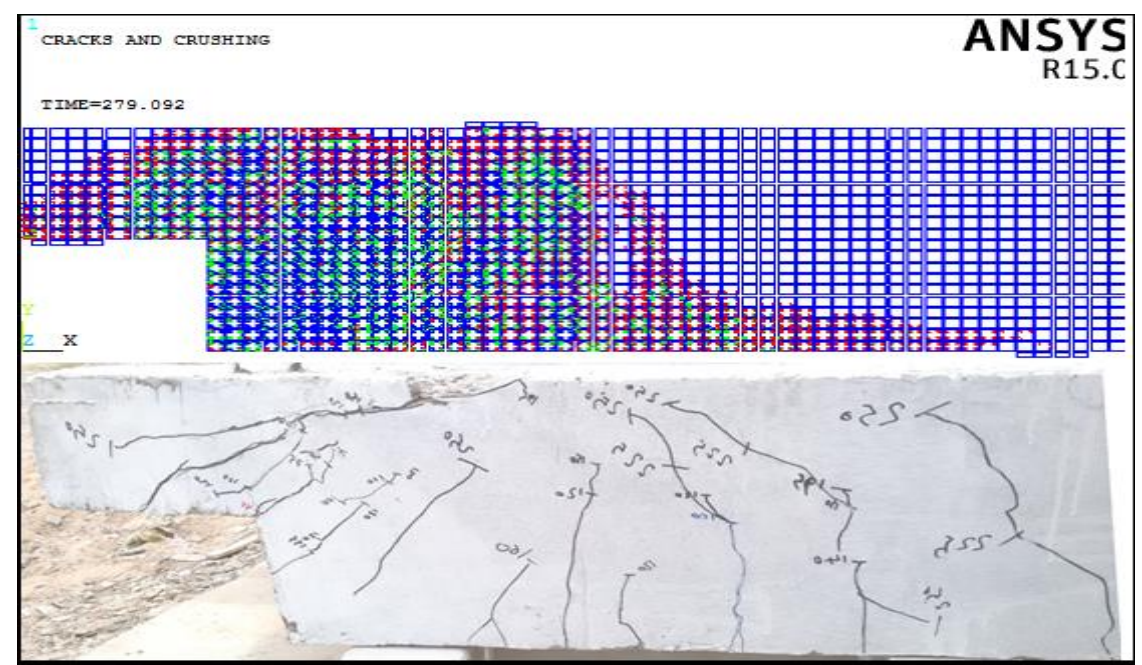

Figure (25) Cracking Patterns at Ultimate Load for CONT-A

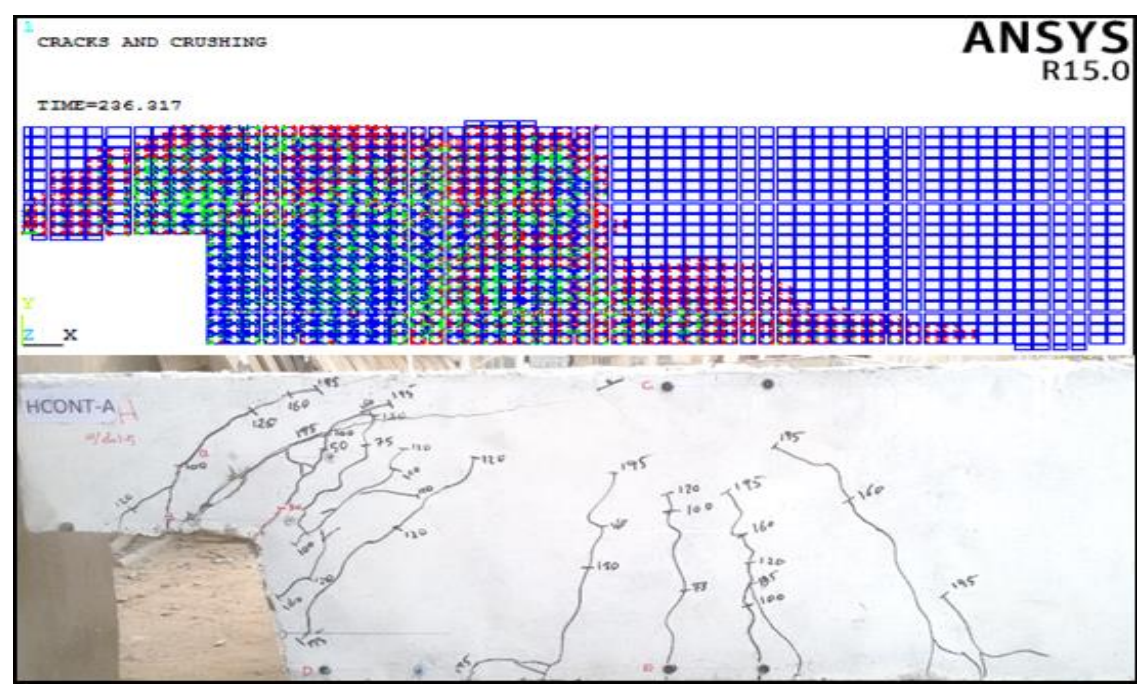

Figure (26) Cracking Patterns at Ultimate Load for HCONT-A 
Journal of University of Babylon for Engineering Sciences, Vol. (26), No. (7): 2018.

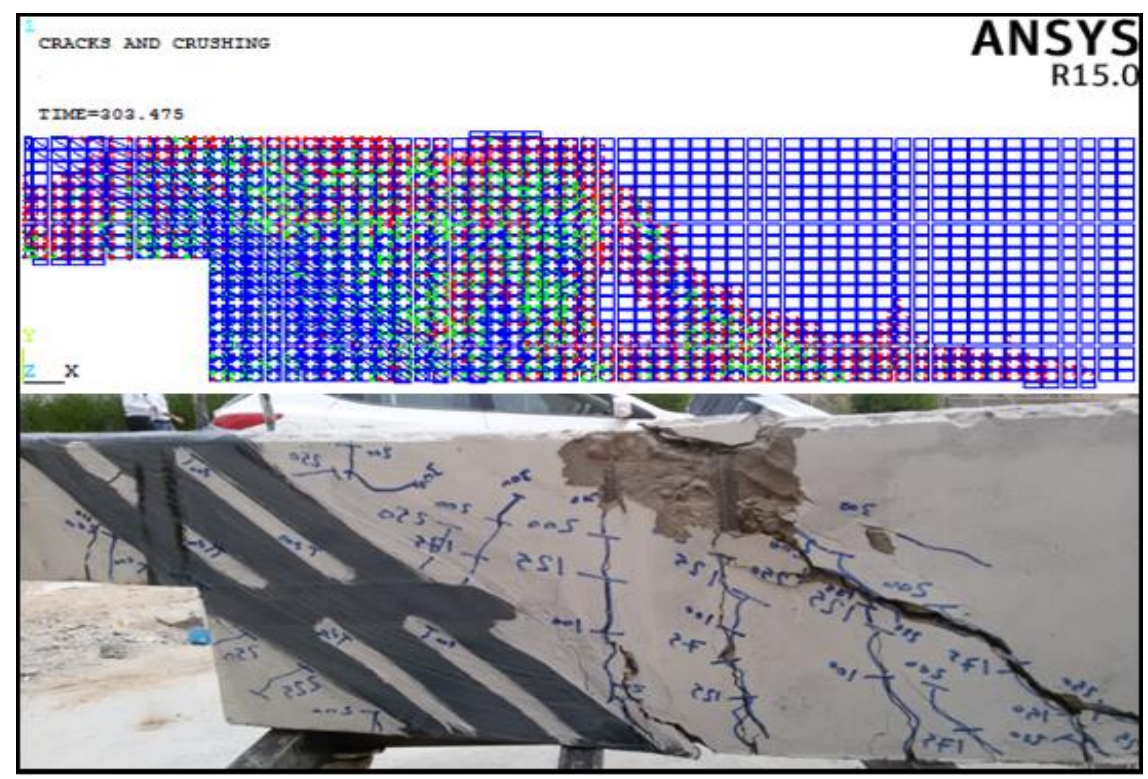

Figure (27) Cracking Patterns at Ultimate Load for HSTR1-A

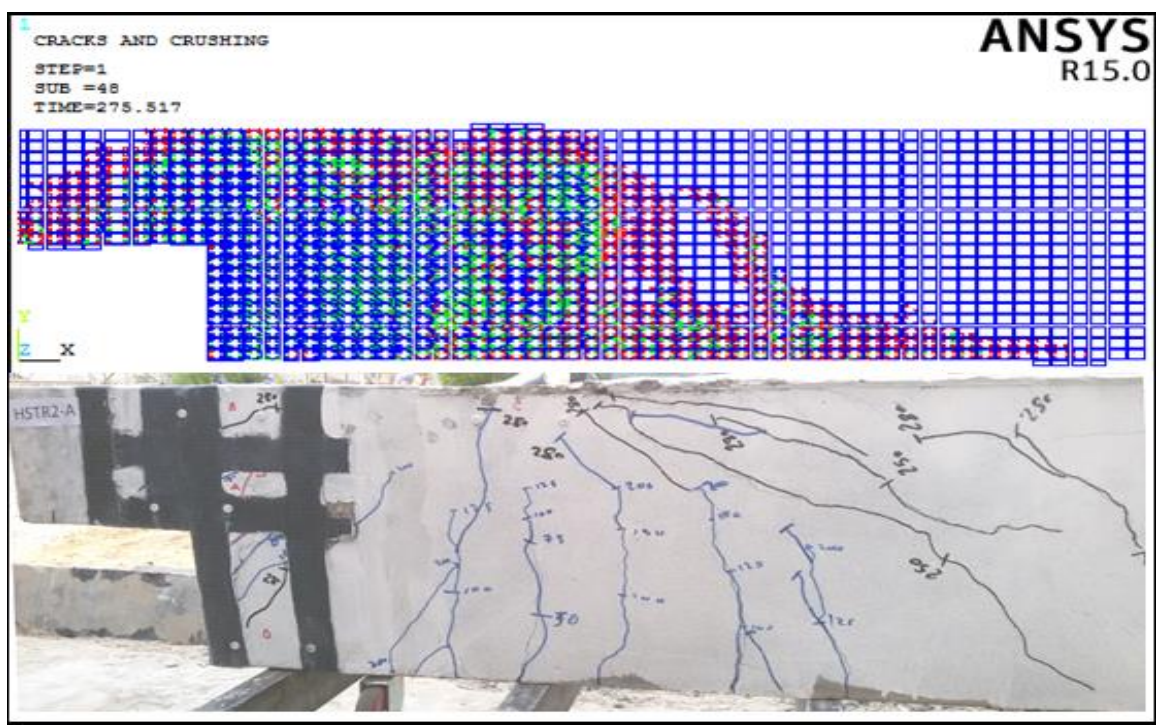

Figure (28) Cracking Patterns at Ultimate Load for HSTR2-A

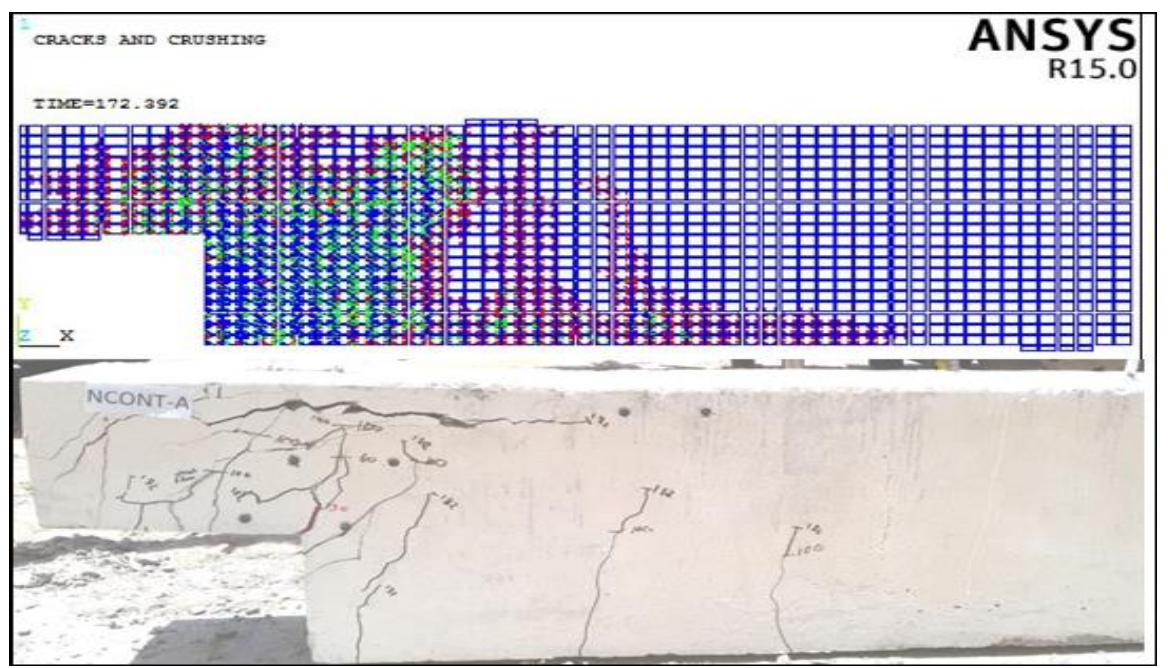

Figure (29) Cracking Patterns at Ultimate Load for NCONT-A 


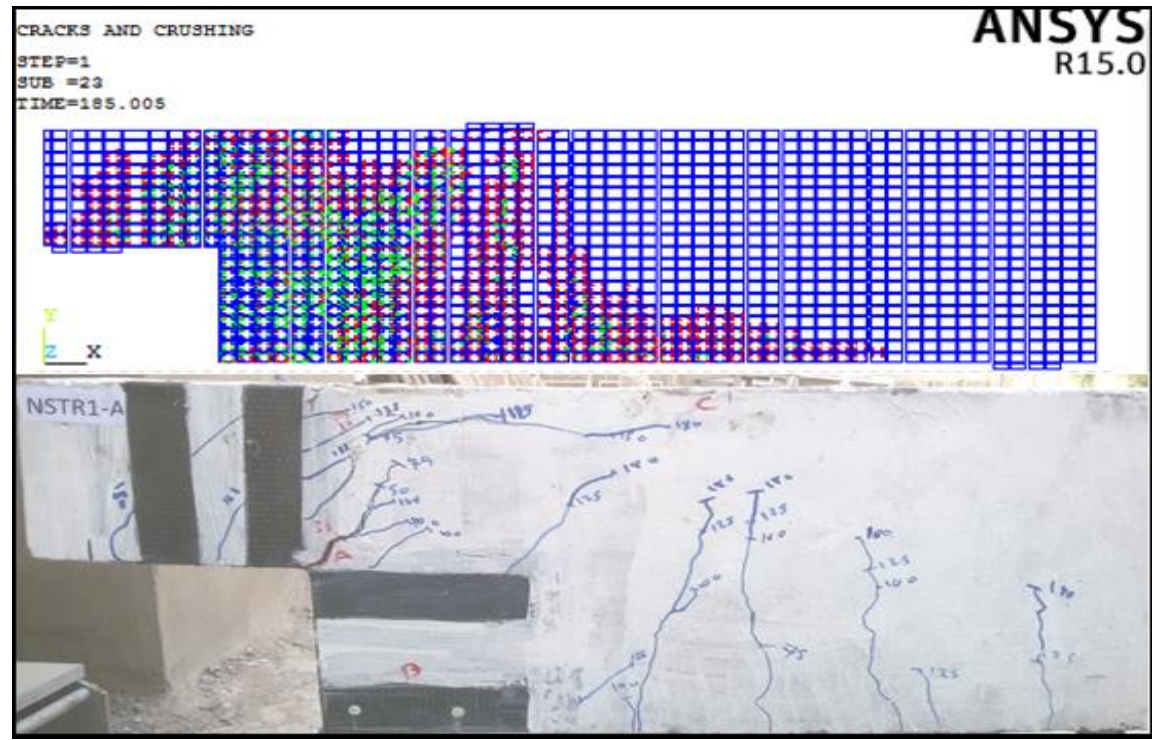

Figure (30) Cracking Patterns at Ultimate Load for NSTR1-A

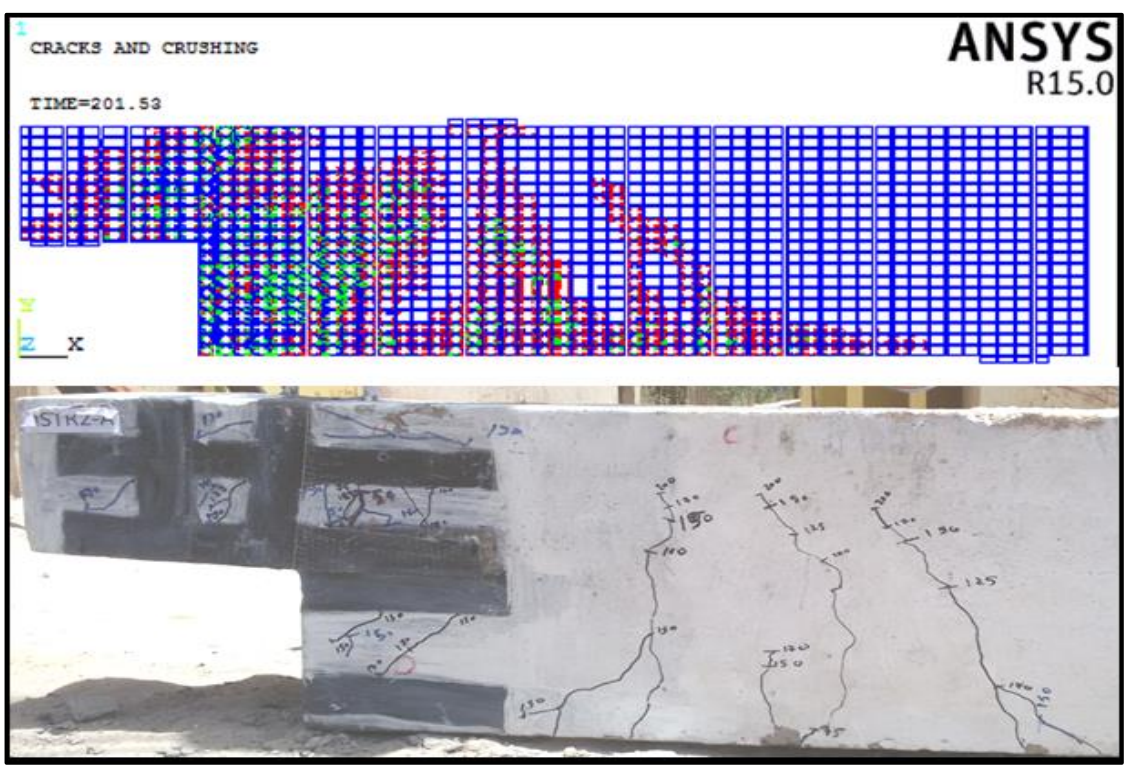

Figure (31) Cracking Patterns at Ultimate Load for NSTR2-A

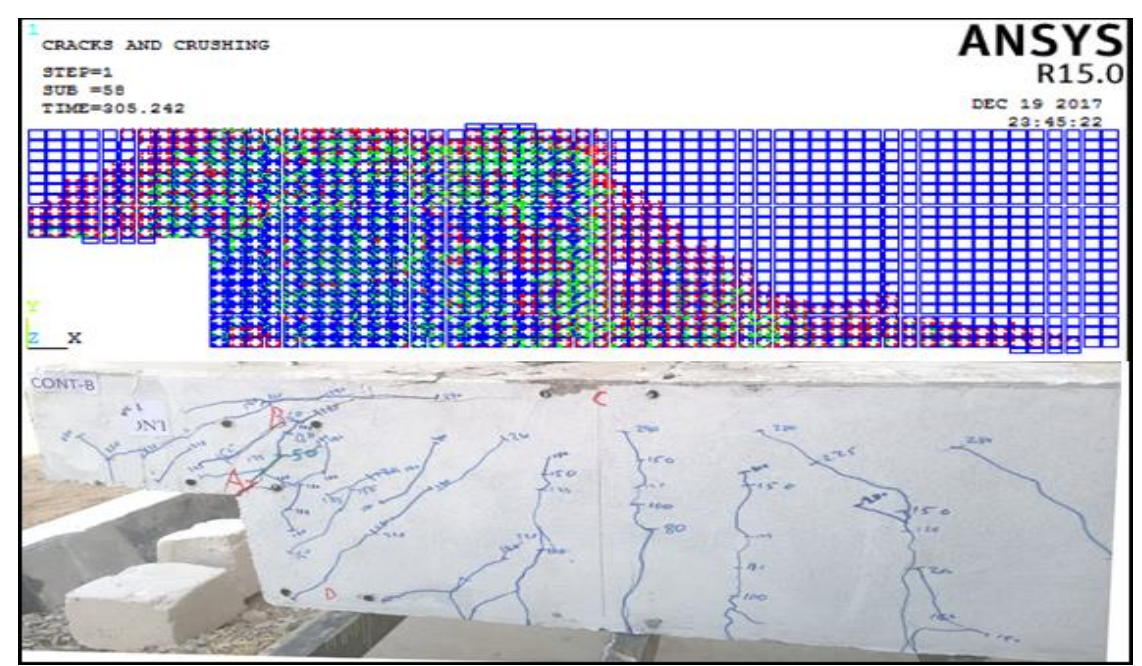

Figure (32) Cracking Patterns at Ultimate Load for CONT-B 
Journal of University of Babylon for Engineering Sciences, Vol. (26), No. (7): 2018.

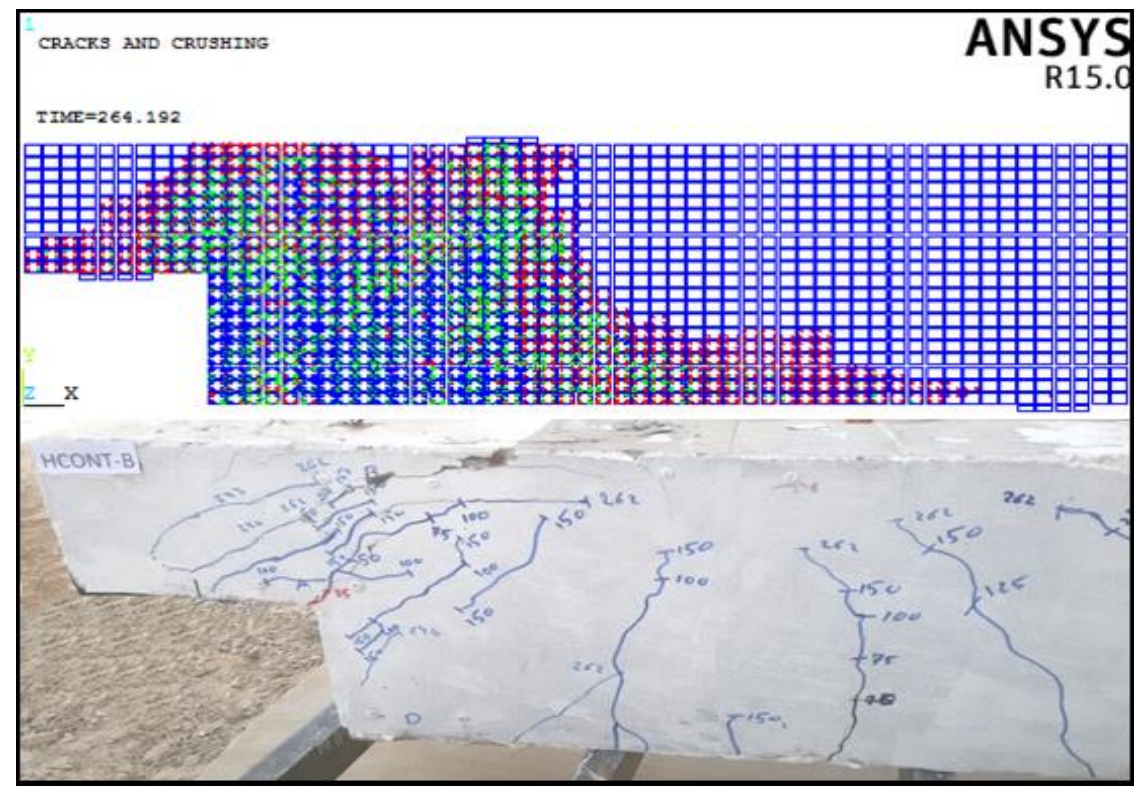

Figure (33) Cracking Patterns at Ultimate Load for HCONT-B

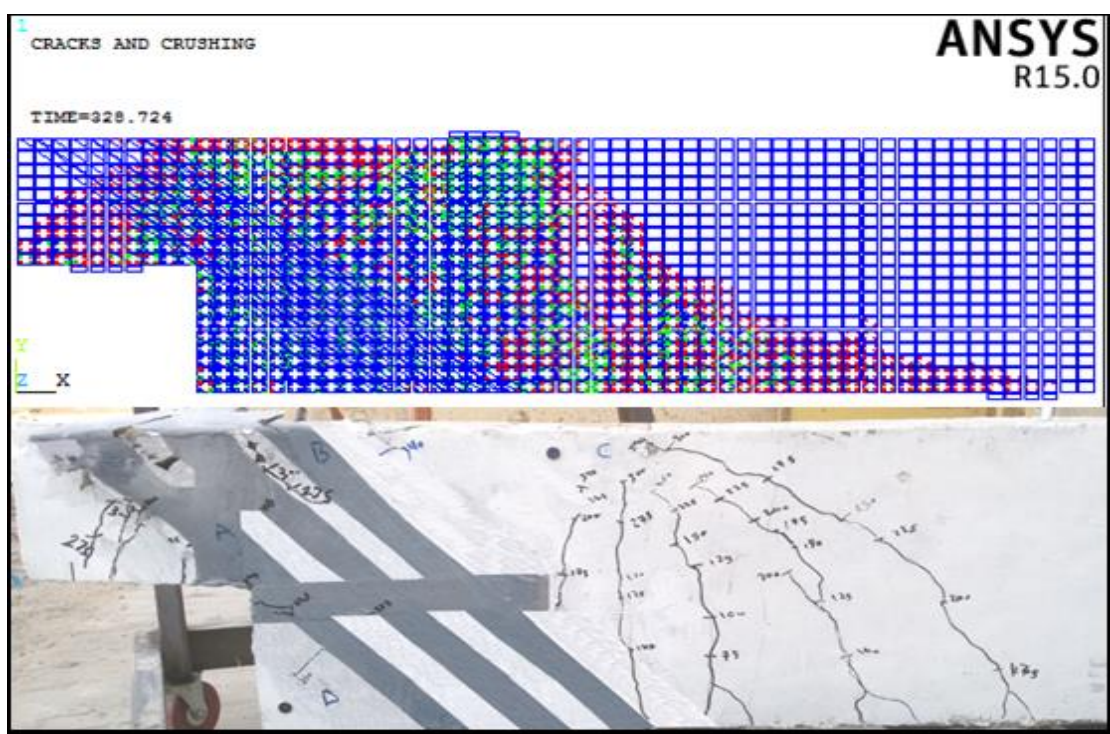

Figure (34) Cracking Patterns at Ultimate Load for HSTR1-B 
Journal of University of Babylon for Engineering Sciences, Vol. (26), No. (7): 2018.

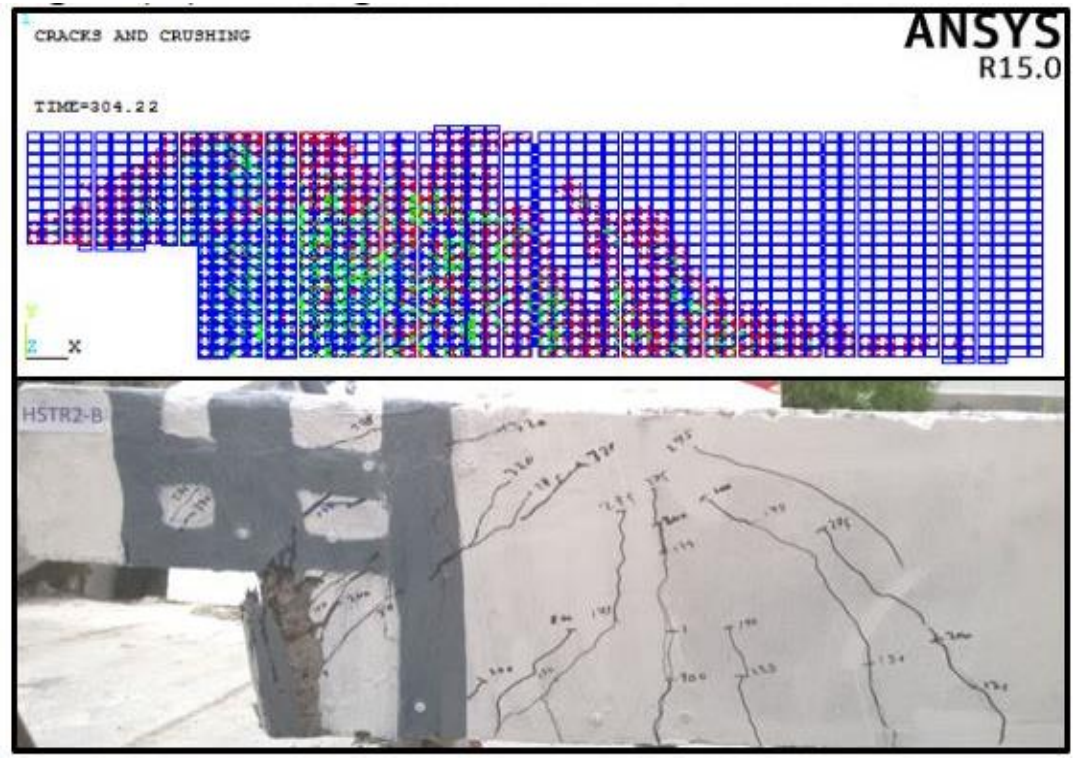

Figure (35) Cracking Patterns at Ultimate Load for HSTR2-B

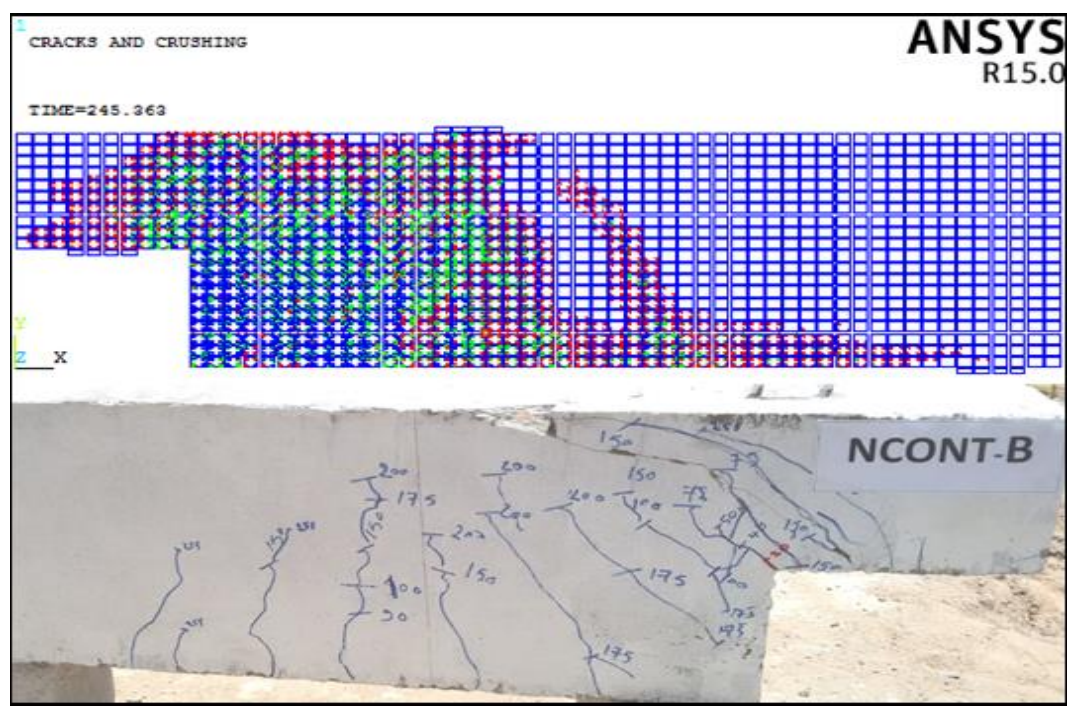

Figure (36) Cracking Patterns at Ultimate Load for NCONT-B

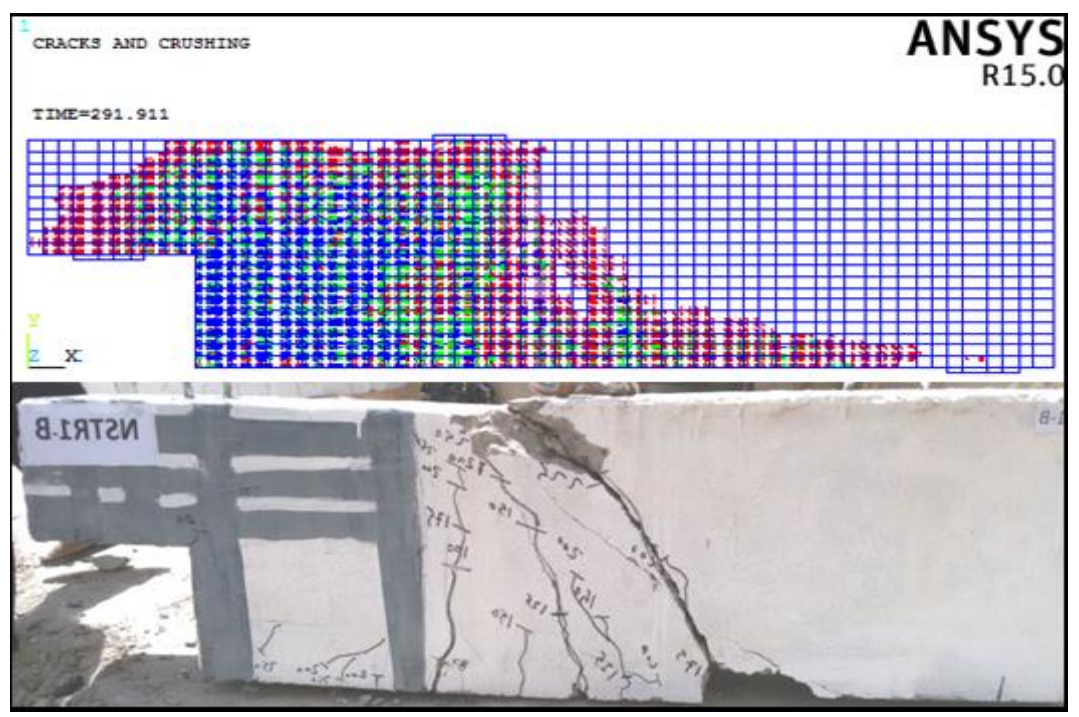

Figure (37) Cracking Patterns at Ultimate Load for NSTR1-B 


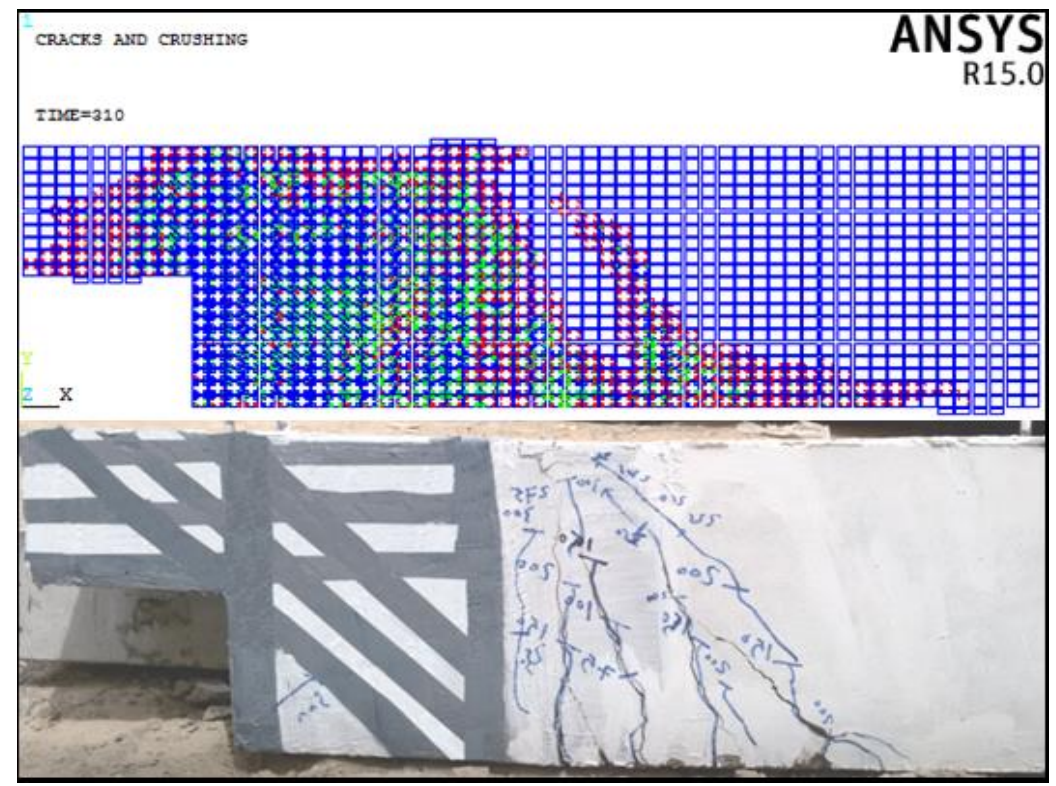

Figure (38) Cracking Patterns at Ultimate Load for NSTR2-B

\section{Conclusions}

The main findings obtained from results of the experimental work and finite element analysis, are listed below:

1- For the control specimens (with full-reinforcement), reducing (a/d) ratio from (1.5) to (1.0), led to increase in load capacity by about (17\%) and shifting the mode of failure from diagonal tension in the extended end to the diagonal tension in the reentrant corner.

2- Reducing hanger reinforcements by about (50\%), results in reduction for failure load about (13\%), while the reduction of nib reinforcement by about $(60 \%)$, reduced failure load about $(35 \%)$ and $(15 \%)$ for $\mathrm{a} / \mathrm{d}=1.5$ and $\mathrm{a} / \mathrm{d}=1.0$ respectively, this is because that the STM model is conservative somehow.

3- The strengthening with CFRP sheets improved both the shear strength and general performance of dapped ends. The increment in load capacity for beams strengthened hanger regions with inclined strips for a/d (1.5 and 1.0) was about (17\% and $23 \%$ ) respectively, and for strengthening with vertical strips was about (11\% and $18 \%)$ for a/d (1.5 and 1.0$)$ respectively.

While, for beams nib regions strengthened was $(\mathrm{a} / \mathrm{d})=1.5$ was about $(10 \%)$ for L-shape sheets with horizontal strips. Also, for $(\mathrm{a} / \mathrm{d})=1.0$ with inclined strips was about $(15 \%)$.

4- Strengthening with CFRP sheets has a considerable effect on first cracking load, for specimens strengthened in hanger regions by inclined strips the increment was found $(80 \%$ and $72 \%)$ with $(\mathrm{a} / \mathrm{d})(1.5$, and 1.0) respectively, , while, for strengthening by vertical strips the increment was about $(72 \%$ and $75 \%)$ for $(\mathrm{a} / \mathrm{d})$ (1.5, and 1.0), respectively. Also for specimens strengthened in nib regions by inclined and horizontal strips, the increment was found $(80 \%$ and $75 \%$ ) for $(\mathrm{a} / \mathrm{d}=1.0)$, while, for $(\mathrm{a} / \mathrm{d}=1.5)$ the increment was $(26 \%$ and $50 \%)$ for strengthening with L-shape CFRP sheet and horizontal CFRP strips, respectively . 
5- It is found the F.E model efficient to present the nonlinear behavior of the SCC dapped ends subjected to static loading strengthening or un-strengthening with CFRP sheets. The comparing between the numerical and the experimental results yielded a good agreement, where the average of differences between the predicted and experimental loads was about (12\%).

6- The finite element model behavior was found to be stiffer than that of the tested specimen due to the effect of bond slip between the concrete and steel bars between concrete and CFRP sheet, and the effect of the micro cracks in concrete is excluded in the finite element analysis.

\section{References}

[1]Liem S. K., "Maximum Shear Strength of Dapped-end or Corbel" M. Sc. Thesis, College of Engineering, University Concordia, Montreal, Quebec, Canada, August 1983.

[2]Mattock A. H., and Chan T. C., Design and Behavior of dapped End Beams”, PCI Journal, V.24, No. 6, pp. 28-45, November-December 1979.

[3]Wang Q. , Guo Z. and Hoogenboom P. C. J., "Experimental Investigation on the Shear Capacity of RC Dapped end Beams and Design Recommendations", Structural Engineering and Mechanics, V. 21, No. 2, pp. 221- 235, 2005.

[4]Dhia S. and Khudair T., "Strength Enhancement of Prestressed Concrete DappedEnd Girders", College of Engineering- University of Baghdad, Number 10, Volume 21, Journal of Engineering, October 2015.

[5]Amir W. et al., "Dapped ends of prestressed concrete thin-stemmed members", PCI Journal, March-April 2017.

[6]Iraqi specification No. 5, "Portland Cement", Baghdad, الجهاز) المركزي للتقييس وو السيطرة النوعية), 1984.

[7]Iraqi specification No. 45, "Natural Sources for Gravel that is Used in Concrete and Construction", Baghdad, (الجهاز المركزي للتقييس والسيطرة النوعية), 1984.

[8]EFNARC, "Specification and Guidelines for Self-Compacting Concrete". Association House, 99 West Street, Farnham, Surrey, London, UK, 32pp. http;//www.emarc.org, E-mail:poulson@btinternet.com, February 2002.

[9]ASTM C-494/C 494M -01, "Standard Specification for Chemical Admixtures for Concrete", Annual Book ofAmerican Society for Testing and Materials, 2001.

[10] Sika, "SikaWrap-301 C", Technical data sheet, Sika Corporation, 16/1/2015 edition.

[11] Sika, "Sikadur 330", Technical data sheet, Sika Corporation, 13/6/2006 edition.

[12]ACI Committee 237R-07, "ACI 237R-07 Self-Consolidating Concrete" Farmington Hills, Michigan; American Concrete Institute, 2007. 


\section{التحريات العلمية و النظرية للأعتاب الخرسانية الذاتية الرص ذات النهايات المستدقة و المقواة بشرائح ألياف الكاربون البوليمرية لئه

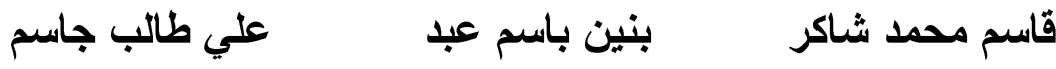 قسم مواد الانثائية، كلية الهنسة، جامعة الكوفة}

alit.albozwaida@uokufa.edu.iq baneenbasim507@gmail.com gasimm.alabbasi@uokufa.edu.iq

\section{الخلاصة}

الهدف من هذه الدراسة هو النحري عمليا عن سلوك الاعتاب الخرسانية الذاتية الرص ذات النهايات

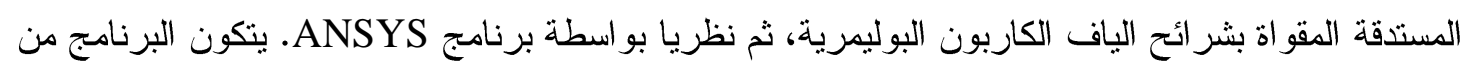

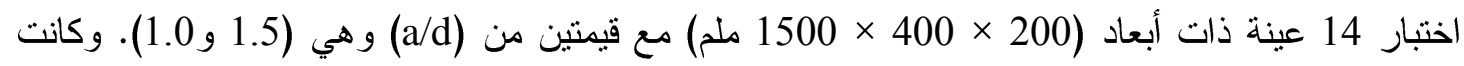

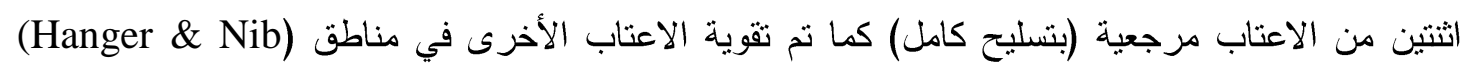

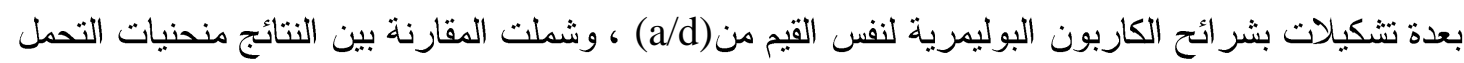

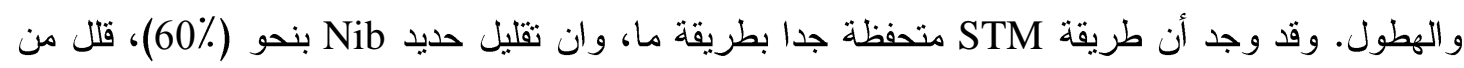

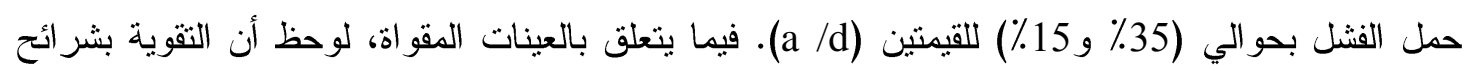

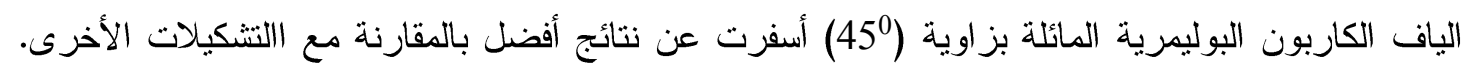

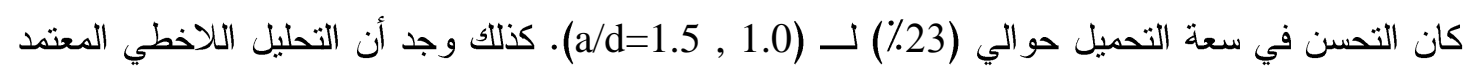

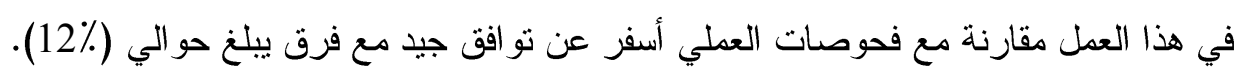
الكلمات المفتاحية: - العتب ذات النهاية المستدقة، فضاء القص الى العق الفعال، شرائح الكاربون

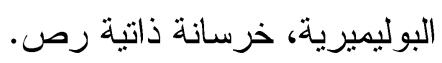

